\title{
Povezanost teorije uma s socialnimi odnosi in otrokovo socialno kompetentnostjo
}

\author{
Nuša Skubic*
} Ljubljana

Povzetek: Prispevek predstavlja pregled in evalvacijo ugotovitev raziskovalcev s področja teorije uma v povezavi s socialnimi odnosi in na drugi strani v povezavi z otrokovo socialno kompetentnostjo, ki je odraz njegove teorije uma. Prikazuje, kateri so tisti dejavniki, ki največ prispevajo $\mathrm{k}$ individualnim razlikam v razvitosti teorije uma med otroki in poudarja dvosmernost učinkov med otrokovim socialnim razumevanjem in socialnimi odnosi z drugimi. Pozitivni dejavniki za razvoj otrokove teorije uma so v prvi vrsti otrokove zgodnje kakovostne izkušnje o mentalnih stanjih, ki dobro napovedujejo njegov poznejši dosežek pri preizkusu razumevanja napačnih prepričanj. Od družinskih dejavnikov so za razvoj otrokove teorije uma pomembni predvsem socialno-ekonomski položaj družine, vedenje in govor staršev (npr. ustrezna raba izrazov za opisovanje mentalnih stanj in ustrezni načini discipliniranja otroka) in prisotnost ustrezno starega (ponavadi starejšega) sorojenca, $\mathrm{s}$ katerim ima otrok kakovosten odnos, medtem ko raziskovalci izmed dejavnikov, ki niso vezani na družinsko okolje, najbolj poudarjajo pomen vrstnikov za otrokovo teorijo uma. Skladno s temi dejavniki se pri otroku bolj ali manj uspešno razvija njegovo socialno razumevanje, ki igra pomembno vlogo v njegovem vsakdanjem življenju. Tako otroci z dobro razvito teorijo uma to lahko uporabljajo na prosocialen način, lahko pa ta služi tudi proaktivni oziroma posredni obliki agresivnosti, ko otroci svoje razumevanje drugih uporabljajo za različne oblike manipulacij oz. nasilništva, posebej v vrstniški skupini. Nizko razvita teorija uma je dejavnik tveganja predvsem $v$ primeru neugodnih družinskih razmer, medtem ko ima dobro razvita teorija uma v takih razmerah za otrokov razvoj lahko zaščitno vlogo. Prispevek opozarja na nekatere metodološke in strukturne pomanjkljivosti pregledanih študij ter predlaga usmeritve za možnosti celovitejšega raziskovanja otrokove teorije uma v prihodnje.

Ključne besede: teorija uma, socialni odnosi, socialna kompetentnost, socialno vedenje, Vygotsky, agresivnost

\section{Association of theory of mind with social relations and child's social competence}

\author{
Nuša Skubic \\ Ljubljana, Slovenia
}

\begin{abstract}
The article reviews and evaluates the findings from the research in the field of theory of mind; how the theory of mind is connected to social relationships and how a child's social competence reflects his/hers theory of mind. It points to those factors that contribute most to considerable individual differences among children when developing a theory of mind and it stresses out the reciprocity of effects between child's social understanding and social relations with others. Positive factors for developing a theory of mind are first of all child's early quality experiences about mental states which predict a child's performance on the false belief test later on. Social-economic status, parental behavior and talk (for example appropriate use of mental states and appropriate disciplining of a child) and presence of sibling of appropriate age (usually older one) with whom a child develops a quality relationship are most important family factors for theory of mind development. The role of peers is most important factor outside the family, emphasized by studies. In accordance with these factors a child develops more or less successfully his/hers social understanding which plays an important part in his/hers daily life. Children with well developed theory of mind can use it in a pro-social way, or it can serve proactive or reactive aggression when children use their understanding of others as a way of manipulating and bullying, especially inside their peer group. Poorly developed theory of mind can prove to be a risk factor especially in a bad family situation, while a well developed theory of mind can play a protective role in child's development. The article points out some of the deficiencies of reviewed studies and proposes options for more complex future research of child's theory of mind.
\end{abstract}

Keywords: theory of mind, social relations, social competence, social behaviour, Vygotsky, aggression

${ }^{*}$ Naslov/Address: Nuša Skubic, Ziherlova 4, 1000 Ljubljana; e-pošta: nusa.skubic@gmail.com

Članek je licenciran pod pogoji Creative Commons Attribution 4.0 licence. / The article is licensed under a Creative Commons Attribution 4.0 International License. 
Teorija uma je ena najpomembnejših otrokovih socialno-spoznavnih sposobnosti, največji premik $\mathrm{v}$ njenem razvoju pa se zgodi med tretjim in petim letom starosti (Wellman, Cross in Watson, 2001). Gre za otrokovo sposobnost razumeti, da ima vsak posameznik svojo mentalno sliko o realnosti, ki je lahko različna od t. i. »objektivne realnosti« in od mentalnih slik drugih ljudi. Mentalna slika je odvisna od razpoložljivih informacij in se lahko pri isti osebi spreminja v času. Otrokova naloga je, da se nauči razumeti sebe in druge ljudi kot ljudi, ki imajo svoje želje, prepričanja, čustva, namere in lastne interpretacije sveta (Marjanovič Umek, 2009).

Razvoj teorije uma je postopen (Marjanovič Umek, 2009). Pri dveh letih otrok osvoji enostavno teorijo uma, imenovano psihologija želja, ko razume, da je vedenje drugega pod vplivom njegovih želja. Pri treh letih nastopi stopnja psihologija prepričanja - želje, ko otrok prepričanja drugih razume kot posnetke realnosti, ne interpretacije realnosti. Nekje med tretjim in petim letom se pri otroku razvije reprezentacijska teorija uma, kot to stopnjo imenuje Perner (Perner, 1991; v Marjanovič Umek, 2009) oz. razumevanje prepričanj kot interpretacij in reprezentacij, kot ji pravi Welman (Welman, 1990; v Marjanovič Umek, 2009). Razumevanje napačnih prepričanj pri otroku lahko izmerimo $\mathrm{z}$ različnimi uveljavljenimi nalogami, med katerimi sta najpogostejši naloga z deklicama Sally in Ann (Frith, 1989; v Marjanovič Umek, 2009) in naloga z zavajajočo škatlo (Perner, Leekam in Wimmer, 1987; v Marjanovič Umek, 2009).

Področje teorije uma se je $\mathrm{v}$ teoretskem smislu najprej umeščalo na področje spoznavnega razvoja (npr. Wellman idr., 2001), vedno bolj pa se poudarja tudi njen socialni vidik (npr. Perner, Ruffman in Leekam, 1994). Med otroki obstajajo precejšnje razlike $v$ tem, kdaj osvojijo teorijo uma - v povprečju se to zgodi v četrtem letu starosti, pri nekaterih pa že pri treh letih in pri drugih šele pri petih ali še kasneje (Wellman idr., 2001). Iskanje vzroka za te individualne razlike $\mathrm{v}$ razvoju teorije uma je tako izhodiščni problem mnogih študij z raziskovalno zelo bogatega področja otrokovega socialnega razumevanja (npr. Peterson, 2000; Ruffman, Perner in Parkin, 1999). Pričujoči prispevek po eni strani predstavlja pregled študij, ki ponujajo možne odgovore na vprašanje, kateri so tisti najpomembnejši dejavniki, odgovorni za individualne razlike v razvoju teorije uma, in na kakšen način nanjo učinkujejo, pri čemer že v začetku prvega dela pojasnimo, zakaj se osredotočamo na različne mere otrokovega okolja in ne na genetske dejavnike. Prvi del prispevka tako temelji na predpostavki, da otroci s kakovostnejšimi socialnimi izkušnjami prej razvijejo teorijo uma (npr. Pears in Moses, 2003). Sledi obravnava okoljskih dejavnikov, ki so glede na empirične podatke pregledanih študij zaslužni za razlike $\mathrm{v}$ razvoju teorije uma otrok, in sicer dveh dejavnikov družinskega okolja (značilnosti govora staršev in prisotnost sorojencev) ter enega, ki zajema otrokove izvendružinske izkušnje (učinek vrstnikov). Po drugi strani prispevek ponuja vpogled v razvoj otrokove teorije uma tudi $\mathrm{z}$ druge perspektive. $\mathrm{V}$ drugem delu se namreč posvečamo učinkom teorije uma na otrokove socialne interakcije ter osvetlimo odnos med otrokovim socialnim razumevanjem in njegovim socialnim vedenjem, natančneje otrokovo socialno kompetentnostjo. V prispevku obenem izpostavljamo problematiko smeri učinkov med otrokovim socialnim razumevanjem in socialnimi interakcijami z drugimi ter predpostavljamo, da so ti učinki dvosmerni. Izhodišče drugega dela je tako predpostavka, da raven razvitosti teorije uma pogojuje značilnosti oz. naravo otrokovih interakcij z drugimi, saj teorija uma vključuje otrokovo znanje o načinu delovanja posameznikovih misli, hotenj itd. (Carpendale in Lewis, 2006a, 2006b). Izpostavimo tudi neprimernost predpostavljanja enostavne pozitivne povezanosti med dobro razvito teorijo uma otroka in dobrimi socialnimi odnosi $z$ drugimi.

Prispevek je rezultat analize prek 150 znanstvenih virov s področja raziskovanja teorije uma, v katerih avtorji iščejo povezave otrokove teorije uma s socialnim življenjem otrok. Pri tem poseže na široka raziskovalna področja, kot je teoretska struktura koncepta teorije uma, njeno merjenje, njena vloga $v$ razvoju otrok $z$ ne-normativnim razvojem (npr. avtistični otroci, gluhi otroci), njena povezanost z razvojem govora, njen razvoj zunaj okvira razvojnega mejnika okrog četrtega leta starosti (teorija uma predpostavlja stopenjski razvoj) ter se jih dotakne le v luči opisanega raziskovalnega problema. $\mathrm{V}$ prispevku združujemo ugotovitve mnogih raziskovalcev s področja povezanosti teorije uma s socialnim življenjem otrok in jih razdelimo v dva sklopa na način, da se izpostavi problematika smeri učinkov na obravnavanem področju. Prispevek ponuja strnjen pregled znanstvenih virov, $\mathrm{v}$ katerih avtorji empirično dokazujejo povezanost teorije uma s posameznimi dejavniki oz. področji iz otrokovega okolja, med katerimi pa se večina osredinja na bolj ali manj en dejavnik in zanemarjajo vlogo ostalih. Prispevek poskuša preseči empirične omejitve teh raziskav v smislu, da ustvari širšo sliko za razumevanje individualnih razlik, ki nastajajo pri otrocih v razvoju njihove teorije uma.

\section{Pomen socialnih odnosov za razvoj teorije uma}

Za razvoj otrokovega socialnega razumevanja, kamor se umešča tudi teorija uma, so izjemnega pomena njegove vsakodnevne socialne izkušnje. Uspešni socialni odnosi v zgodnjem otroštvu namreč predstavljajo priložnost za otrokovo učenje o odnosu 
med posameznikovim mišljenjem in vedenjem (Walker, 2005).

Ko gre za razumevanje dedljivosti teorije uma, torej za razumevanje tega, kolikšen del medosebnih razlik pojasnijo genetski dejavniki, študije ne podajajo enotnih rezultatov. Po podatkih $\mathrm{C}$. Hughes in sodelavcev (2005) so genetski učinki na tem področju zanemarljivi, saj dejavniki okolja (in sicer tako tistega, ki si ga sorojenci v isti družini delijo, kot tistega, ki si ga ne) pojasnijo večino variabilnosti $v$ razvoju teorije uma pri petletnih dvojčkih, genetski dejavniki pa samo $15 \%$. Avtorji vedenjskogenetskih študij tudi sicer poudarjajo, da so za otrokov razvoj pomembni predvsem tisti vidiki okolja, ki si ga otroci v isti družini ne delijo, tj. za posameznega otroka specifični dogodki, ki ga oblikujejo bolj različnega od sorojenca, kot so bolezen, izvendružinski odnosi (npr. v vrtcu), pa tudi individualen odnos $\mathrm{z}$ istimi osebami v družini, vrstni red rojstev in razlikovalno odzivanje staršev (Kavčič in Zupančič, 2006). Medtem sta po drugi strani C. Hughes in A. L Cutting (1999) odkrili pomemben genetski učinek na teorijo uma, obenem pa nobenega učinka okolja, ki si ga delijo sorojenci znotraj iste družine. Razloge za te razlike $\mathrm{v}$ ugotovitvah različnih avtorjev bi lahko iskali že v velikosti vzorcev in s tem povezano statistično močjo, saj je bil npr. vzorec najprej opisane študije (Hughes idr., 2005) zelo velik glede na to, da gre za genetsko študijo, in predvsem neprimerno večji od tistega, ki sta jo opravili C. Hughes in A. L. Cutting (1999; 1116 parov nasproti 119 parom dvojčkov). Vzorec $\mathrm{V}$ prvi raziskavi je poleg tega zajemal otroke družin $\mathrm{z}$ nižjim socialno-ekonomskim položajem, obenem pa so bili otroci, vključeni v prvo študijo, v povprečju skoraj dve leti starejši in zato morda izpostavljeni več izvendružinskim izkušnjam kot otroci, vključeni $\mathrm{v}$ drugo študijo, ali pa gre za to, da so bili pri različnih starostih izmerjeni različni vidiki teorije uma (Ronald, Happe, Hughes in Plomin, 2005). Študija A. Ronald in sodelavcev (2005) je prinesla rezultate, ki so nekje vmes med navedenima študijama; teorija uma se je pri dve, tri in štiri leta starih otrocih izkazala za srednje visoko dedljivo in pomembno povezano tako z dejavniki okolja, ki si ga otroci v isti družini med seboj delijo, kot tudi s tistimi iz okolja, ki si ga ne. Prvo je imelo pomembnejšo vlogo pri mlajših otrocih. Da so za razvoj teorije uma pomembnejši okoljski kot genetski dejavniki in da je teorija uma zmerno visoko dedljiva, je potrdila tudi študija, v kateri so avtorji preučevali pare dvojčkov v srednjem otroštvu (Ronald, Viding, Happe in Plomin, 2006), in sicer pri starosti devetih let.

Iz navedenih ugotovitev je moč sklepati, da gre pri razvoju teorije uma za zapleteno interakcijo med genetskimi in okoljskimi dejavniki, pri čemer se $\mathrm{v}$ nadaljevanju posvečamo slednjim. Pomen osebnih interakcij otroka $\mathrm{z}$ drugimi za razvoj teorije uma nakazujejo tudi izsledki študij pri gluhih otrocih slišečih staršev, ki imajo težave pri razvoju teorije uma (Woolfe, Want in Siegal, 2002). Osebe, s katerimi otroci $\mathrm{v}$ zgodnjem otroštvu najpogosteje vstopajo $\mathrm{v}$ socialne interakcije in naj bi imele najpomembnejšo vlogo pri oblikovanju njihove teorije uma, so starši, sorojenci in vrstniki (Carpendale in Lewis, 2006a). $\mathrm{Na}$ tem mestu pa je potrebno opozoriti, da v primeru družin $\mathrm{z}$ več kot enim otrokom navedeni družinski dejavniki niso enoznačne mere bodisi okolja, ki si ga otroci v isti družini delijo bodisi okolja, ki si ga ne. Starši (njihov govor, pripisovanje uma otroku, odnos do otrok in slog starševstva) so sicer lahko skupna mera okolja, a v resnici so ponavadi individualna (občutljivo odzivanje staršev na individualne potrebe posameznih otrok) (Kavčič in Zupančič, 2006). Nadalje je v zvezi z učinkom sorojencev na otrokovo teorijo uma število otrok enaka mera za vse otroke v družini, vrstni red rojstev pa individualna. Tretji dejavnik, tj. vrstniško skupino, obravnavamo kot mero okolja, ki si je otroci v isti družini ne delijo.

\section{Vloga staršev v razvoju otrokove teorije uma}

Glavni koncepti, ki na ravni odnosov med starši in otrokom lahko igrajo pomembno vlogo pri razvoju otrokove teorije uma, so značilnosti govora staršev (tudi govor staršev, ki ni naslovljen neposredno na otroka), kakovost odnosa (predvsem tip navezanosti) in slog starševstva (npr. Hughes in Ensor, 2006; McElwain in Volling, 2004; Symons, Fossum in Collins, 2006).

\section{Značilnosti govora staršev}

Čeprav avtorji navajajo različne interakcijske vplive, študije o pomenu otrokovih pogovorov s starši večinoma potrjujejo velik pomen določenih vsebin oz. vidikov pogovorov s starši za razvoj otrokove teorije uma (pregled v de Rosnay in Hughes, 2006), in sicer predvsem v okviru sociokulturne teorije Vygotskega. Otrok teorije uma ne osvoji sam od sebe; otrok se uči v območju bližnjega razvoja, ki predstavlja razliko med njegovo dejansko in potencialno ravnjo razvoja, do katere lahko pride ob pomoči kompetentne osebe (Fernyhough, 2008; Vygotskij, 2010). Razvoj teorije uma je tako delno funkcija socialnega prenosa med starši in otroki. Dober dokaz za to je študija, ki je primerjala teorijo uma pri otrocih iz vzgojnih institucij, otrocih iz družin $\mathrm{z}$ nizkim socialno-ekonomskim položajem in pri tistih iz srednjega razreda (Yagmurlu, Berument in Celimli, 2005). Otroci, vzgojeni v institucijah, kjer imajo veliko stikov $\mathrm{z}$ drugimi otroki in malo kakovostnih interakcij z odraslimi, so bili pri nalogah za ocenjevanje teorije uma precej manj uspešni kot otroci, ki živijo s svojimi starši. Spremenljivka 
število odraslih na otroka je bila dober napovednik otrokove uspešnosti pri nalogah za ocenjevanje teorije uma tudi ob nadzoru socialno-ekonomskega položaja družine ter otrokove starosti, govorne kompetentnosti in neverbalne inteligentnosti. Avtorji študije so zato sklepali, da je kljub materialni prikrajšanosti otrok iz vzgojnih institucij (skromno število starosti primernih igrač in knjig, odsotnost občutka lastništva nad njimi ipd.) verjetno pomanjkanje individualnega odnosa $\mathrm{s}$ kompetentno osebo (odraslim) tisto, kar predstavlja glavni razlog za manj razvito teorijo uma. Skladno z ugotovitvami avtorjev te študije tako lahko rečemo, da so otrokove interakcije $\mathrm{z}$ odraslo osebo posebej pomembne $\mathrm{v}$ okoliščinah, ko so za teorijo uma vzpodbudni dejavniki okolja omejeni.

Za razvoj otrokove teorije uma je pomembna predvsem starševska raba izrazov za opisovanje mentalnih oz. notranjih stanj (npr. Hughes, Fujisawa, Ensor, Lecce in Marfleet, 2006; Sabbagh in Callanan, 1998), tj. prepričanj, zaznavanja, hotenja itd. Ker med starši obstajajo razlike $\mathrm{v}$ tem, koliko $\mathrm{v}$ svoj govor vključujejo izraze za opisovanje mentalnih stanj, se je v študijah uveljavil koncept pripisovanje uma (ang. mindmindedness), ki označuje nagnjenje staršev k temu, da svoje otroke obravnavajo kot samostojne osebe $\mathrm{z}$ lastnimi mislimi in čustvi; da se torej pri opazovanju otrok osredotočijo na njihove mentalne značilnosti in ne zgolj na vedenjske in fizične lastnosti (Symons idr., 2006). Ta spremenljivka se pomembno povezuje z otrokovo teorijo uma. Skozi jezik in pogovor namreč starši otroku omogočijo, da razmišlja in govori o lastnih mentalnih stanjih in mentalnih stanjih drugih. Na splošno velja, da otroci, ki so uspešni pri reševanju nalog za ocenjevanje teorije uma bolj zgodaj v razvoju, pogosteje prihajajo iz družin, v katerih se starši pogosto pogovarjajo s svojimi otroki o mentalnih stanjih (npr. Brown, Donelan-McCall in Dunn, 1996). Raziskovalci so odkrili povezanost med otrokovo teorijo uma in govorom mame tako med igro $\mathrm{z}$ dojenčkom (Meins idr., 2002), kot tudi med skupnim branjem in pripovedovanjem zgodb (Symons, Peterson, Slaughter, Roche in Doyle, 2005) ter podobnimi dejavnostmi, ki omogočajo rabo izrazov za opisovanje mentalnih stanj. Vendar pa se zdi navedena spoznanja smiselno nadgraditi z ugotovitvami drugih študij, ki navajajo, da zgolj uporaba pojmov za označevanje mentalnih stanj ni dovolj za spodbujanje otrokovega socialnega razumevanja. Dosežki otrok na nalogah za ocenjevanje teorije uma se namreč povezujejo $\mathrm{z}$ razlaganjem, izpostavljanjem vzrokov in odkrivanjem nasprotij $\mathrm{v}$ materinem govoru o teh pojmih (Slaughter, Peterson in Mackintosh, 2007).

Dolgoročne pozitivne učinke materine zgodnje ozaveščenosti o otrokovi teoriji uma so na podoben način prikazale tudi vzdolžne študije (Meins idr., 2002;
Symons idr., 2006). Symons in sodelavci (2006) so ugotovili, da je materino ustrezno (glede na otrokov odziv) govorjenje o hotenjih (ne pa tudi o spoznanjih) med igro $\mathrm{z}$ dvoletnikom dober napovednik razvitosti teorije uma otroka pri približno petih letih starosti, in sicer neodvisno od materine občutljivosti, socialnoekonomskega položaja družine in otrokove govorne kompetentnosti. Avtorji študije poudarjajo, da so ti izsledki skladnis socialnokonstruktivističnimpristopom, ki govori o tem, da otrokove zgodnje komunikacijske izkušnje o mentalnih stanjih dobro napovedujejo njegov poznejši dosežek pri preizkusu napačnih prepričanj. Obenem avtorji te študije pripisujejo velik pomen ustrezni rabi izrazov za opisovanje mentalnih stanj, in sicer takšni, ki vključuje razlage in izpeljave $\mathrm{V}$ dvosmerno komunikacijo $\mathrm{z}$ otrokom ter ustvari primeren okvir za otrokovo miselno aktivnost znotraj pogovora, saj bo le kot taka imela dejanski učinek na otrokovo razumevanje mentalnih stanj. Zaključijo, da otrokovo socialno razumevanje izhaja najprej iz soočanja z izrazi za hotenja, kar se kasneje izgradi v razumevanje prepričanj; po četrtem letu starosti je tako diskurz o hotenjih najverjetneje slabši napovednik otrokove teorije uma kot prej.

Učinek narave pogovorov s starši na otrokovo teorijo uma je podprla tudi študija L. L. Ontai in Thompsona (2008). Avtorja sta preučevala dve dimenziji pogovora med mamo in otrokom ter ugotovila, da je materin usmerjevalni pogovor (ang. elaborative talk) boljši napovednik otrokove teorije uma kot njeni izrazi za opisovanje mentalnih stanj, ki za razliko od prejšnjih študij (Ruffman, Slade, Devitt in Crowe, 2006; Symons in Clark, 2000) niso bili povezani z razvitostjo otrokove teorije uma. Ta rezultat je morda posledica obstoja različnih kategorij izrazov za opisovanje mentalnih stanj, med katerimi niso vse enako pomembne za razvoj teorije uma. Menimo, da bi morali avtorji $\mathrm{v}$ tem primeru ugotavljati povezanost otrokove teorije uma s posameznimi kategorijami izrazov (npr. hotenja, čustva, predstave ipd.) (npr. Symons idr., 2006). Tako pa so omenjeni rezultati lahko odvisni od vsebine materinih pogovorov z otrokom, ki lahko zajemajo različne količine izrazov iz posameznih kategorij. Do tega prihaja, ker različni raziskovalci materino uporabo izrazov za opisovanje mentalnih stanj merijo različno, npr. nekateri na podlagi prostega materinega govora otroku o skupnem dogodku iz preteklosti (Ontai in Thompson, 2008), drugi na podlagi materinega pogovora $\mathrm{z}$ otrokom ob sliki (Ruffman idr., 2006) itd. Pri usmerjevalnem pogovoru gre za materino implicitno ali eksplicitno odzivanje na otrokovo predstavo o dogodkih v smislu ponujanja alternativnih interpretacij oz. vrednotenja njegove predstave ali spodbujanja otrokovega razumevanja prek podajanja informacij o čustvih, željah, mislih in 
motivih drugih. Usmerjevalni pogovor torej služi kot kontekst za otrokovo spoznanje, da imajo druge osebe o isti izkušnji lahko drugačno prepričanje kot on, in ga prisili, da upošteva različne poglede na neko situacijo. Podobno je Racine s sodelavcema (Racine, Carpendale in Turnbull, 2006) preučeval govor mater v odnosu do njihovih otrok v konfliktnih situacijah, in sicer so ga avtorji vrednotili glede na njegovo pojasnjevalno naravo. Pojasnjevalni govor je bil pri otrocih, starih med tri in pet let, ob nadzoru starosti in skupnega učinka govora pozitivno povezan $\mathrm{z}$ otrokovim razumevanjem prepričanj in čustev. Pojasnjevalni govor za razliko od ne-pojasnjevalnega, ki zgolj izpostavi rešitev, usmerja pozornost otroka $\mathrm{k}$ namenom in posledicam dejanj, ki so sprožile konflikt.

\section{Navezanost otroka na starše}

Bowlbyjeva etološka teorija navezanosti govori tudi o tem, da kakovost navezanosti otroka na mater oblikuje njegovo razumevanje sebe in drugih (Bowlby, $1969 \mathrm{v}$ Ontai in Thompson, 2008). Rezultati študij o povezanosti med otrokovo navezanostjo na pomembne druge osebe in razvojem teorije uma so si nasprotujoči, saj nekateri avtorji navajajo, da obstaja neposredna povezanost med otrokovo teorijo uma in tipom navezanosti (Meins, Fernyhough, Russell in Clark-Carter, 1998; Symons in Clark, 2000), medtem ko drugi o tej povezanosti ne poročajo (Ontai in Thompson, 2008). Tako npr. N. L. McElwain in B. L. Volling (2004) navajata, da otroci, ki so deležni večje občutljivosti s strani svojih staršev in so nanje varno navezani pri enem letu starosti, bolj verjetno uspešno opravijo preizkus napačnih prepričanj pri štirih letih starosti. Nadalje so E. Meins in sodelavci (1998) v vzdolžni študiji ugotovili, da otroci, ki so bili v obdobju dojenčka varno navezani, pri štirih letih starosti dosegajo boljše rezultate na preizkusu napačnih prepričanj od otrok, ki kot dojenčki niso bili varno navezani. Za razhajanja med izsledki študij o tem, ali je teorija uma povezana $\mathrm{z}$ otrokovo navezanostjo na pomembne osebe, so verjetno zaslužne različne intervenirajoče spremenljivke, na kar nakazuje študija L. L. Ontai in Thompsona (2008), ki sta prišla do drugačnih ugotovitev od pravkar navedenih. V svoji študiji sta poleg povezanosti teorije uma s tipom navezanosti otroka na mater preučevala, ali je mogoče $\mathrm{s}$ tipom navezanosti pojasniti variabilnost $\mathrm{v}$ razvoju teorije uma tudi takrat, ko v analize vključimo mere, ki se nanašajo na značilnosti pogovora med materjo in štiriletnim otrokom (tj. materin usmerjevalni pogovor in pogostost materinih izrazov za opisovanje mentalnih stanj v pogovoru). Čeprav sta avtorja glede na teoretska izhodišča (pri katerih sta izhajala iz teorije navezanosti) o pomenu odprte komunikacije znotraj varne navezanosti otroka na mamo pričakovala povezanost med otrokovo navezanostjo na mamo in njegovo teorijo uma, se otrokova navezanost ni izkazala kot dober napovednik razvitosti otrokove teorije uma. Otrokova navezanost niti v interakcji skupaj s katero od obeh spremenljivk iz sklopa značilnosti pogovora matere $\mathrm{z}$ otrokom ni bila dober napovednik teorije uma. Avtorja prav tako nista odkrila povezanosti med varno navezanostjo in materinim govorom. Na področju raziskovanja povezanosti med otrokovo navezanostjo in teorijo uma torej ostaja veliko nejasnosti, različnost ugotovitev pa morda lahko pripišemo že omenjenim različnim načinom merjenja materinega govora, nereprezentativnim vzorcem, različni količini in izboru nalog s področja ocenjevanja teorije uma ipd.

\section{Slog starševstva}

Na razvoj otrokove teorije uma učinkuje tudi slog starševstva. Avtorji ugotavljajo, da dvoletni malčki staršev z avtoritarnim slogom vzgoje in z manj razvitimi sposobnostmi s področja zgodnje teorije uma kažejo več vedenjskih težav, in sicer so te s slogom starševstva in teorijo uma povezane tako neposredno, kot tudi skozi njuno skupno delovanje (Hughes in Ensor, 2006). Obenem se povezanost med avtoritarnim starševstvom in malčkovim težavnim vedenjem zmanjša, če ima malček dobro razvite sposobnosti s področja teorije uma, kar lahko pomeni, da služijo kot zaščitni dejavnik. Nadalje avtoritarno starševstvo in teorija uma pri dveh letih starosti neodvisno in $\mathrm{v}$ interakciji predstavljata dober napovednik za vedenjske težave pri štirih letih starosti, in sicer tudi ob nadzoru vedenjskih težav pri dveh letih, verbalnih sposobnosti in socialnega položaja družine (Hughes in Ensor, 2007). Sklepamo lahko, da bolj razvito socialno razumevanje malčka deluje kot zaščitni dejavnik vedenjskih težav v primeru avtoritarnega starševstva.

Povezanost teorije uma $\mathrm{z}$ različnimi vidiki oz. dimenzijami starševstva je odvisna tudi od otrokovega spola. Medtem ko je starševska toplina pomembnejša za razvoj teorije uma pri deklicah, je pri dečkih bolj pomemben starševski nadzor (Hughes, Deater-Deckard in Cutting, 1999). Med deklicami in dečki torej očitno obstajajo razlike $\mathrm{v}$ tem, kako svoje zavedanje o umu uporabljajo $\mathrm{v}$ odnosih $\mathrm{z}$ drugimi (o tem vidiku sicer obširneje govorimo v drugem delu prispevka). Deklice so npr. bolj kot dečki nagnjene k uporabi znanja o umu na področjih čustvene opore, empatije in sodelovanja. Avtorji študije poudarjajo podvrženost odnosov med spremenljivkami na tem področju tudi kulturnim normativnim spolnim vlogam in opozarjajo na verjetne medkulturne razlike.

Ruffman in sodelavci (1999) so ugotovili povezanost otrokovega razumevanja napačnih prepričanj $\mathrm{z}$ materinim poročanjem o njenem načinu ravnanja 
v konfliktnih situacijah, $\mathrm{v}$ katerih morajo svojega otroka disciplinirati. Matere, ki so disciplinirale z izpostavljanjem občutkov tistega, ki je tarča otrokovega neprimernega ravnanja, so imele otroke $z$ bolj razvito teorijo uma, medtem ko splošno materino razpravljanje $\mathrm{z}$ otrokom o njegovem neprimernem ravnanju za otrokovo teorijo uma ni bilo pomembno. Nadalje sta K. C. Pears in L. J. Moses (2003) ugotovili pozitivno povezanost med materino uporabo napotkov v odzivanju na otrokovo (starost 3-5 let) neprimerno ravnanje in njegovim razumevanjem zaznavanja in hotenj, materino posluževanje tehnik dokazovanja moči pa se je $\mathrm{z}$ otrokovo teorijo uma povezovalo negativno. Avtorici menita, da imajo tehnike dokazovanja moči (vključno z vpitjem, fizičnim kaznovanjem in neposrednim ukazovanjem) negativne posledice za otrokov spoznavni razvoj, saj otroku preprečujejo, da bi se svoje probleme naučil reševati sam. Obenem usmerjajo pozornost na razlike $\mathrm{v}$ moči med njim in starši ter lahko povzročijo, da bo otrok odgovornost za svoja dejanja prenašal na okolico, namesto, da bi jo prevzel nase. Vsekakor je potrebno upoštevati, da je smer povezanosti lahko tudi obratna, in sicer da starši otrok z manj razvito teorijo uma uporabljajo več tehnik dokazovanja moči, ker so te pri njihovih otrocih morda bolj učinkovite od drugih vzgojnih pristopov (Pears in Moses, 2003).

Poleg staršev pa imajo pomembno vlogo pri vzpostavljanju socialnih interakcij tudi otrokovi sorojenci in vrstniki. Po navedbah ene od študij (Brown idr., 1996) otroci celo mnogo več izrazov za opisovanje mentalnih stanj uporabljajo $\mathrm{v}$ pogovorih s svojimi brati oz. sestrami in prijatelji kot $\mathrm{v}$ pogovorih $\mathrm{z}$ materjo, kar se povezuje tudi $\mathrm{z}$ njihovim dosežkom na preizkusu napačnih prepričanj.

\section{Vloga sorojencev $\mathbf{v}$ razvoju otrokove teorije uma}

Mnogo študij kaže na to, da možnost socialne interakcije $\mathrm{z}$ drugim(-i) otrokom(-ki) $\mathrm{V}$ družini predstavlja prednost za razvoj socialnega razumevanja nad učinkom, ki ga ima na otroka njegova interakcija s starši. Pionirsko študijo o učinkih sorojencev na teorijo uma so izvedli Perner in sodelavci (1994). Ugotovili so, da triletniki z dvema sorojencema naloge za ocenjevanje teorije uma opravijo enako dobro kot štiriletniki brez sorojencev, otroci z enim sorojencem pa bolje kot otroci brez sorojencev (pri tem vrstni red rojstev sorojencev ni bil pomemben). Podobno so neodvisne učinke števila sorojencev na individualne razlike $\mathrm{v}$ teoriji uma potrdile tudi mnoge kasnejše študije (npr. Jenkins in Astington, 1996; McAlister in Peterson, 2006).

Ruffman, Perner, Naito, Parkin in Clements (1998) so $\mathrm{z}$ drugačnimi postopki ponovili analize na podatkih, ki so jih pridobili Perner in sodelavci (1994), poleg tega pa postopke ponovili še na vzorcu 300 angleških in japonskih otrok, starih od tri do pet let, ter ugotovili, da učinek sorojencev ni tako enostaven in vezan samo na število sorojencev. Pozitiven učinek na razvoj otrokove teorije uma imajo tako le starejši, ne pa tudi mlajši sorojenci (pri čemer se ti učinki pokažejo šele, ko so otroci starejši od treh let in dveh mesecev). Starejši otroci namreč prevzamejo vlogo kompetentne osebe, ki se razlikuje od tiste, ki jo imajo $\mathrm{v}$ tem procesu starši, ter v okviru območja bližnjega razvoja (Vygotskij, 2010) skozi igro (npr. prikazovanje uporabe različnih igrač, prevzemanje vlog $\mathrm{v}$ igri pretvarjanj ipd.) in uporabo izrazov za opisovanje mentalnih stanj povzdignejo otrokovo razumevanje drugih na višjo raven. Obenem lahko takšne interakcije s sorojenci služijo kot kompenzacijski dejavnik pri govorno manj kompetentnih otrocih (Jenkins in Astington, 1996). Starejše študije (npr. Perner idr. 1994) za razliko od študije Ruffmana in sodelavcev (1998) niso jasno razmejile učinka mlajših in učinka starejših sorojencev oz. če so ga, niso upoštevale točnega števila enih in drugih, zato niso uspele odkriti tovrstnega učinka starejših sorojencev, ki ga lahko ustrezno pojasnimo s teorijo Vygotskega (2010).

K. W. Cassidy, D. S. Fineberg, K. Brown in A. Perkins (2005) so primerjale razvitost teorije uma pri tri- do petletnikih, in sicer med otroki $\mathrm{z}$ enim sorojencem, dvojčki brez drugih sorojencev, dvojčki s še drugimi sorojenci in edinci. Med drugim so ugotovile, da dvojčki brez drugih sorojencev ne dosegajo boljših rezultatov na nalogah za ocenjevanje teorije uma $\mathrm{v}$ primerjavi $z$ edinci, so pa celo manj uspešni od otrok $\mathrm{z}$ enim sorojencem. Ti dvojčki in pari sorojencev nedvojčkov sicer $\mathrm{v}$ svojem vsakdanu približno enako časa namenijo verbalni komunikaciji, igri pretvarjanja ter sodelovanju in prepirom $\mathrm{z}$ bratom ali sestro, a dosegajo različne ravni razvitosti teorije uma. Avtorice ugibajo, da so dvojčki manj uspešni morda zato, ker sta si uma dvojčkov preveč podobna, lahko pa tudi zaradi drugačnega odnosa staršev do svojih otrok, če gre za dvojčka. Dva otroka na isti stopnji razvoja namreč zahtevata hkratno dvojno pozornost staršev na vseh področjih, zato ju morda redkeje vključujejo v pogovor o mentalnih stanjih in $\mathrm{v}$ pogovor nasploh, kot bi ju v primeru, da bi bila edina otroka te starosti, kar poudarjajo tudi Thorpe, Rutter in Greenwood (2003, v Cassidy idr., 2005). Taka ugibanja so sicer nekoliko nagla, saj bi jih bilo potrebno preveriti s študijo, ki bi dejansko merila razlike $\mathrm{v}$ pogostnosti in značilnostih pogovorov staršev $\mathrm{z}$ otroki, starimi približno štiri leta, glede na to, ali gre za npr. štiriletne dvojčke, štiriletne dvojčke s sorojenci ali štiriletnika $\mathrm{z}$ različno starim sorojencem. Najverjetneje je sicer res razlika $v$ starosti med sorojencema in s tem raznolikost njune 
komunikacije tista, ki pospešuje razvoj teorije uma, in ne zgolj obstoj sorojenca in komunikacija $\mathrm{z}$ njim kot taka (Peterson, 2000), saj ima otrok v interakciji s starejšim (vloga učenca) oz. mlajšim (vloga učitelja) bratom ali sestro več priložnosti za zavzemanje perspektive drugega, ki je bolj verjetno različna od njegove lastne, kot če bi šlo za vrstnika. Po drugi strani prevelika razlika v starosti v tem smislu tudi ni ugodna, saj najstniki ne vstopajo pogosto $\mathrm{v}$ interakcije s precej mlajšimi sorojenci, dojenčki ali malčki pa ne zmorejo pozitivno učinkovati na razvoj teorije uma sorojenca. Po navedbah Petersona (2000) morajo biti sorojenci za obstoj pozitivnih učinkov le-teh na razvoj teorije uma pri tri- do petletnih otrocih stari od dvanajst mesecev do dvanajst let, saj bodo le v tem primeru taki tri- do petletni otroci izražali bolje razvito teorijo uma od edincev.

Navedeno je potrdila tudi študija Lewisa in sodelavcev (1996), obenem pa razkrila, da otroci, ki imajo poleg osnovne nuklearne družine še pogoste interakcije na dnevni ravni $\mathrm{v}$ okviru razširjene družine (npr. s starimi starši, bratranci), pri nalogah za ocenjevanje teorije uma dosežejo še posebej dobre rezultate. Logistična regresija v tej študiji je pokazala, da so dejavniki, ki pojasnijo največ variance dosežkov pri nalogi za ocenjevanje teorije uma, a) število odraslih sorodnikov oz. odraslih, s katerimi je otrok dnevno v interakcijah, b) otrokova starost, c) število starejših sorojencev in d) število starejših otrok, s katerimi je otrok dnevno $v$ interakcijah.

Ker so vse do sedaj navedene študije prečne, v resnici ne moremo govoriti o smeri učinkov sorojencev na razvoj teorije uma. Tovrstno pomanjkljivost sta presegli A. McAlister in C. Peterson (2007) v vzdolžni študiji pri 63 avstralskih otrocih povprečne starosti štiri leta in dva meseca ob prvem merjenju razumevanja napačnih prepričanj ter pet let in štiri mesece ob drugem. Neodvisno od njihove kronološke starosti so otroci z dvema ali več sorojenci dosegli bolšje rezultate kot edinci tako pri prvem kot pri drugem testiranju. Rezultat drugega testiranja je dobro napovedovalo število sorojencev tudi ob nadzoru starosti, verbalne inteligentnosti in rezultata prvega merjenja. Opraviti imamo torej z odnosom med spremenljivkama, ki ni vezan samo na določeno starost, ampak je najverjetneje značilen za celotno obdobje zgodnjega otroštva. Avtorici poudarjata, da čeprav vzdolžna študija in narava preučevanih konceptov veliko trdneje pričata o vplivu sorojencev na teorijo uma kot o obratni smeri povezanosti, se $v$ ta odnos še vedno lahko vključuje še tretja spremenljivka. Obenem navajata, da vzorec razmeroma visoko izobraženih staršev lahko pomeni, da se ti starši bolj zavedajo pomena uma (otroku pripisujejo um, kot smo že omenili) in zaradi tega njihova pogosta raba izrazov za opisovanje mentalnih stanj spodbuja razvoj teorije uma pri otrocih ali pa ti starši bolj spodbujajo svoje otroke $\mathrm{k}$ vključevanju $\mathrm{v}$ socialne interakcije $z$ drugimi. Pri tem ni povsem jasno, čemu služi ta argument, saj pristranost celotnega vzorca glede na izobrazbo staršev ne bi smela imeti učinka na povezanost teorije uma s številom sorojencev, razen če je bila zaradi visoke izobrazbe variabilnost v razvitosti teorije uma manjša in je ta manjša variabilnost na eni spremenljivki znižala korelacije s številom sorojencev. Avtorici ne omenjata povezanosti izobrazbe staršev s številom otrok v družini, ampak govorita o relativno visoki izobrazbi v celotnem vzorcu, pri čemer pa obstaja možnost, da se bolje razvita teorija uma lahko povezuje tudi z boljšo izobrazbo, če bi imeli znotraj vzorca manj izobraženi starši manj otrok oz. obratno. Omejitev omenjene študije je tudi v tem, da je $\mathrm{v}$ celotnem vzorcu samo $16 \%$ edincev in kar 52 $\%$ otrok $\mathrm{z}$ enim sorojencem (preostali otroci so imeli dva ali tri sorojence). Navsezadnje gre lahko tudi za mediatorske vplive spremenljivk, kot so npr. otrokov govor, značilnosti odnosov med sorojenci ipd.

A. L. Cutting in J. Dunn (1999) pa nista ugotovili pomembnih povezav med otrokovim dosežkom na preizkusu napačnih prepričanj in številom sorojencev. Njun vzorec je za razliko od zgoraj opisane študije vseboval veliko gospodinjstev $\mathrm{z}$ nižjim socialnoekonomskim položajem, zaradi česar se morda lažje pokaže učinek sorojencev na otrokovo teorijo uma. Ta učinek je morda odvisen od socialno-ekonomskega položaja otrokove družine $\mathrm{v}$ tem smislu, da morajo najprej obstajati neki minimalni pogoji, da se učinek sorojencev lahko izrazi in potemtakem sam na sebi tudi ne more biti zaščitni dejavnik $\mathrm{v}$ primeru neugodnih socialnih in ekonomskih razmer, kot smo to lahko sklepali pri ugotovljenih učinkih govora staršev na teorijo uma otrok (Yagmurlu idr., 2005). Prednost te študije je tudi relativno velik vzorec $\mathrm{v}$ primerjavi z ostalimi, ki preučujejo iste spremenljivke, saj je vključeval 128 otrok. Na vzorcu dvoletnih malčkov staršev z nižjim socialno-ekonomskim položajem tudi C. Hughes in R. Ensor (2005) nista ugotovili pozitivnih učinkov števila sorojencev za malčkovo teorijo uma, pokazal pa se je pomemben učinek kakovostnega odnosa med sorojencema (ob nadzoru starosti, govornih sposobnosti, izvršitvenih funkcij, socialne prikrajšanosti ter odnosa med starši in otrokom). Učinka sorojencev na otrokovo teorijo uma tako ni ustrezno razlagati samostojno, ampak $\mathrm{V}$ povezavi $\mathrm{z}$ značilnostmi družinskega okolja (izobrazba staršev, socialno-ekonomski položaj, dejavnosti v družini itd.).

Pri preučevanju učinka števila sorojencev na teorijo uma študije navadno ne odgovorijo na vprašanje, kaj je tisto, kar predstavlja prednost za razvoj teorije uma in je učinek sorojenca - je to možnost prisostvovanja pogovorom med sorojencem in starši, možnost 
poslušanja izrazov za opisovanje mentalnih stanj znotraj družine, možnost vključenosti v nesporazume s sorojencem, možnost igranja in pretvarjanja, možnost sodelovanja in oblikovanja strategij skupaj s sorojencem (McAlister in Peterson, 2007)? Iz predpostavke, da je kakovost odnosa med sorojencema tisto, kar je pomembno za razvoj teorije uma, izhaja drugi sklop študij s tega področja, ki se osredotočajo na preučevanje učinka odnosa med sorojenci namesto na učinek števila sorojencev. A. C. Randell in C. C. Peterson (2009) je zanimalo, katere so tiste oblike interakcij med sorojenci, ki v največji meri prispevajo $\mathrm{k}$ razvoju teorije uma. Odločili sta se osredotočiti na različne vidike prepirov med sorojenci, starimi od tri do pet let. Ugotovili sta povezanost dosežka na preizkusu napačnih prepričanj s čustveno dimenzijo prepirov med sorojenci, ne pa tudi z materinim vedenjem ob teh prepirih. Ob nadzoru starosti in govorne kompetentnosti otrok so otroci z višjimi dosežki pri preizkusu napačnih prepričanj izražali manj negativnih in več pozitivnih čustev ob prepirih ter manj distresa po njih. Rezultati kažejo tudi, da teorija uma ni povezana npr. s pogostostjo prepirov med sorojencema, vsebino teh prepirov in tem, ali in kako se razrešijo. Čustveni vidik prepira s sorojencem je torej tisti, ki je najtesneje povezan $\mathrm{z}$ otrokovim razumevanjem napačnih prepričanj. Ugotovitev, da je teorija uma neodvisna tudi od materine uporabe izrazov za opisovanje mentalnih stanj, s katerimi so opisovale prepire svojih otrok $\mathrm{v}$ dnevniških zapisih, je sicer $\mathrm{v}$ nasprotju z nekaterimi prej navedenimi izsledki (npr. Sabbagh in Callanan, 1998) s področja vloge staršev v procesu otrokovega usvajanja socialnega razumevanja. To neskladje bi lahko pripisali že prej omenjenim razlikam v merjenju uporabe izrazov za opisovanje mentalnih stanj (dnevniški zapisi o prepirih morda vključujejo več opisov čustvenih kot miselnih stanj).

$\mathrm{S}$ predpostavko, da prepiri med sorojencema predstavljajo pomemben vir za pridobivanje socialnega znanja, sta svojo študijo s tri- do petletniki zasnovali tudi R. C. Foote in H. A. Holmes-Lonergan (2003). Ugotovili sta, da otroci, ki v prepiru uporabljajo več argumentov, osredotočenih na drugega, dosegajo boljše rezultate na preizkusu napačnih prepričanj. Avtorici nista našli povezanosti s pogostostjo otrokove uporabe izrazov za opisovanje mentalnih stanj med prepirom $\mathrm{s}$ sorojencem, kar pa bi lahko pripisali predvsem načinu njunega kodiranja in kratkemu intervalu opazovanja sorojencev.

Če so prepiri s sorojencem konstruktivni, otroku nudijo priložnost za uporabo utemeljitev in zagovorov, hkrati pa mu pomagajo pri učenju socialnih pravil in norm. V zgodnjem otroštvu se največ prepirov med sorojencema pojavlja med igro, ki je pomembna priložnost za usvajanje pogajalskih strategij. Med drugim se morata otroka zediniti tudi o čustvenih in mentalnih stanjih likov. Tako je pogostejša uporaba izrazov za opisovanje notranjih stanj med prepirom in igro povezana $\mathrm{z}$ višjimi ravnmi pogajalskih strategij, pri čemer gre pri igri tako za uporabo že pridobljenega socialnega razumevanja kot tudi za priložnost za njegov nadaljnji razvoj (Howe, Rinaldi, Jennings in Petrakos, 2002).

$\mathrm{Na}$ pomen kakovosti odnosa med sorojenci za področje preučevanja otrokovega socialnega razumevanja sta opozorili tudi $H$. E. Recchia in N. Howe (2009). Avtorici sta v svoji študiji preučevali povezanost otrokovega socialnega razumevanja in kakovosti odnosa med sorojenci, starimi od štiri do deset let, z njihovimi strategijami reševanja konfliktov, pri čemer sta kot odraz otrokovega socialnega razumevanja poleg dosežka na preizkusu razumevanja napačnih prepričanj (oz. prepričanj drugega reda pri starejših otrocih) merili še otrokovo ocenjevanje konfliktnih situacij. Ugotovili sta, da kakovost odnosa med sorojencema predvsem pri mlajšem sorojencu moderira odnos med otrokovim socialnim razumevanjem in otrokovimi strategijami (konstruktivnimi ali destruktivnimi) reševanja konflikta. Boljše socialno razumevanje torej samostojno ni dober napovednik otrokovega konstruktivnejšega ravnanja v konfliktnih situacijah s sorojencem, ampak je odvisno od kakovosti odnosa med njima.

Nekateri avtorji (Wang in $\mathrm{Su}, 2009$ ) so kategorično kritični do izsledkov študij o učinku sorojencev na teorijo uma v smislu, da učinkov interakcij med otroki ni moč pojasniti samo z interakcijami med sorojenci, saj se otroci družijo tudi z drugimi otroki, vrstniki. Kljub nekaterim pomembnim spoznanjem pregledanih študij je tako potrebno vzeti v obzir, da ti rezultati ne ločujejo učinka sorojencev od učinka vrstnikov na otrokovo teorijo uma.

\section{Vloga vrstnikov v razvoju otrokove teorije uma}

Kitajski avtorici Y. Wang in Y. Su (2009) sta s pomočjo dveh študij primerjali razumevanje napačnih prepričanj pri otrocih brez sorojencev, ki pa se družijo z otroki različnih starosti v vrtcu. Vzorec prve študije je zajemal 30 štiri- in 30 petletnih edincev iz enega od kitajskih vrtcev, ki so bili razdeljeni v dve skupini, in sicer je starostno homogena skupina zajemala otroke $\mathrm{z}$ največ enim letom razlike $\mathrm{v}$ starosti, starostno heterogena skupina pa otroke $\mathrm{z}$ razliko $\mathrm{v}$ starosti od leta in pol do dveh let. S pomočjo binarne logistične regresije sta avtorici ugotovili učinek starosti vrstnikov na dosežke štiriletnih otrok pri nalogah za ocenjevanje razumevanja napačnih prepričanj, in sicer so bili otroci pri teh nalogah uspešnejši, če so prihajali iz skupine $\mathrm{z}$ vrstniki različnih starosti. Avtorici sta dobljene rezultate potrdili še v drugi študiji, in sicer na 
večjem vzorcu štiriletnikov in z uporabo dveh nalog za ocenjevanje teorije uma namesto samo ene, kar pa je še vedno relativno malo. Na podlagi te študije lahko, podobno kot pri nekaterih študijah o učinku sorojencev (npr. Ruffman idr., 1998), sklenemo, da za otrokovo razumevanje napačnih prepričanj ni pomembna količina informacij, temveč narava in kakovost teh informacij.

Nadalje so V. Slaughter, M. J. Dennis in M. Pritchard (2002) v svoji raziskavi ugotavljale, ali je otrokova teorija uma povezana $\mathrm{z}$ njegovo sprejetostjo med vrstniki. Sprejetost so izmerile $\mathrm{z}$ uveljavljeno sociometrično metodo (Coie in Dodge, 1983, v Slaughter idr., 2002), ki temelji na tem, da vsi otroci v skupini imenujejo tri otroke, s katerimi se najraje igrajo, in tri, s katerimi se najmanj radi igrajo. Otrokov socialni položaj med vrstniki se je šibko, a pomembno povezoval z njegovim razumevanjem napačnih prepričanj. Boljše razumevanje izkazujejo otroci, ki so med vrstniki najbolj priljubljeni. Izključeni in zapostavljeni otroci, ki jih vrstniki ne marajo in jih v svojo skupino ne pustijo, imajo glede na izsledke te študije najmanj razvito teorijo uma. Avtorice zaključujejo, da so učinki teorije uma na sprejetost med vrstniki sicer majhni, a se $\mathrm{z}$ otrokovo starostjo povečujejo (pri pet- in šestletnikih je teorija uma boljši napovednik sprejetosti med vrstniki kot pri nižjih starostih). Na tem mestu lahko govorimo o vzajemnih učinkih med otrokovo teorijo uma in njegovo sprejetostjo med vrstniki, saj je mogoče tudi obratno, da se manj priljubljeni otroci zaradi manj izkušenj z vrstniškimi interakcijami ujamejo v spiralo, ki vodi do vedno večjega zaostajanja $\mathrm{v}$ razvitosti teorije uma $\mathrm{v}$ primerjavi z vrstniki. Da pa imajo socialno izključeni otroci (prav tako izmerjeno $\mathrm{z}$ ocenami vrstnikov, ne staršev ali učiteljev) manj razvito teorijo uma kot socialno povprečno sprejeti in najbolj priljubljeni otroci, ni potrdila študija Badenesa, R. A. C Estevan in Bacete (2000). Dosežki socialno izključenih otrok pri nalogah za ocenjevanje področja teorije uma prej nakazujejo na odsotnost prosocialnih sposobnosti kot na odsotnost sposobnosti s področja teorije uma. Avtorji predpostavljajo, da pri starosti, ko socialna izključenost med otroki še ni pogosta (pri otrocih, ki so bili stari med štiri in pet let, je bilo v vzorcu $8 \%$ socialno izključenih otrok) morda ti izključeni otroci res kažejo povprečno razvitost teorije uma. Zaradi pomanjkanja socialnih izkušenj pa socialna izključenost lahko kasneje vodi v primanjkljaj na področju socialnega razumevanja in s tem povezane vedenjske težave (med šest let starimi otroki je bilo v vzorcu $20 \%$ socialno izključenih), kar bi sovpadlo z malo prej navedenim sklepom ob študiji V. Slaughter in sodelavk (2002). Vendarle je to $\mathrm{z}$ vidika narave teh raziskav nekoliko poenostavljen zaključek, saj iz prečnih študij ne moremo sklepati niti o razširjenosti oz. razvoju socialne izključenosti pri istih otrocih pri različni starosti, niti o smeri učinkov med otrokovo socialno izključenostjo in teorijo uma. Pozitivno v tej študiji pa je, da so avtorji za merjenje teorije uma uporabili velik nabor nalog in ne zgolj preizkusa napačnih prepričanj.

Problem pri preučevanju pomena odnosov za razvoj socialnega razumevanja je opredelitev, katera področja socialnega življenja so tista, ki so pomembna za odnos $\mathrm{s}$ teorijo uma, in pa kompleksnost njihovih razmerij z drugimi spremenljivkami. Na primer priljubljenost med vrstniki se razen s teorijo uma (Peterson in Siegal, 2002; Slaughter idr., 2002) povezuje še z ne-socialnimi spremenljivkami, kot so npr. inteligentnost, fizična privlačnost in socialno-ekonomski položaj družine. Ker je pri povezanosti teorije uma z vrstniškimi odnosi smer učinka še posebej verjetno dvosmerna in ker raziskovalci, ki preučujejo socialno izključene otroke, pri njih pogosto opazijo tudi antisocialno vedenje, se razprava o odnosih $\mathrm{z}$ vrstniki nadaljuje $\mathrm{v}$ drugem delu prispevka, ki teorijo uma obravnava $\mathrm{z}$ vidika njenih učinkov na otrokovo socialno vedenje.

\section{Otrokova socialna kompetentnost kot odraz teorije uma}

V vsakdanjem življenju je pogosto pomembno obvladovati model znanja, prepričanj, želja in namenov drugih ljudi (Carpendale in Lewis, 2006b). Pri odnosu med teorijo uma in socialno kompetentnostjo gre torej za prenos otrokovega socialnega razumevanja v njegove vsakodnevne dejavnosti. Mnoge študije dokazujejo, da je socialno razumevanje, ocenjeno z nalogami za ocenjevanje razumevanja napačnih prepričanj, razvojno povezano z značilnostmi otrokovih socialnih interakcij z drugimi. Znano je tudi, da otroci z motnjami avtističnega spektra, za katere je značilno, da imajo velike težave pri razumevanju mentalnih stanj drugih, težko vstopajo v socialne interakcije z drugimi (Peterson, Garnett, Kelly in Attwood, 2009). Čeprav pa je bila povezanost med otrokovim razumevanjem napačnih prepričanj in socialno kompetentnostjo $\mathrm{v}$ raziskovanju že večkrat potrjena, smer povezanosti ostaja nejasna. Ta je, kot poskuša prikazati ta prispevek, najverjetneje dvosmerna. Otrokove izkušnje v socialnih interakcijah predstavljajo priložnost za pridobivanje znanja o odnosu med mišljenjem in vedenjem, to znanje pa hkrati omogoča bolj prilagojeno socialno vedenje.

Socialno razumevanje se povezuje $\mathrm{z}$ različnimi področji razvoja, ki so pomembna za socialno kompetentnost otroka, predvsem $\mathrm{z}$ razumevanjem čustev in moralnim mišljenjem. Lane in sodelavci (Lane, Wellman, Olson, LaBounty in Kerr, 2010) so npr. izvedli vzdolžno študijo, v okviru katere so pri 128 otrocih ocenili čustveno razumevanje in teorijo uma, ko so bili ti stari tri leta in pol ter moralno mišljenje pri njihovih petih letih in pol. Med drugim so ugotovili, da 
sta teorija uma in čustveno razumevanje v medsebojni interakciji dober napovednik višjih kategorij moralnega mišljenja.

V zadnjih letih se precej pozornosti v raziskovanju posveča tudi odnosu med socialnim razumevanjem, socialno kompetentnostjo in spoznavnimi sposobnostmi, ki usmerjajo vedenje, imenovanimi izvršitvene funkcije (Razza in Blair, 2009). Glede na to, da rezultati nekaterih študij govorijo v prid temu, da je socialno razumevanje neodvisen napovednik otrokovih vedenjskih težav, druge pa te povezanosti ne potrjujejo, sta R. A. Razza in C. Blair (2009) opravili vzdolžno študijo, v katero sta vključili tudi spremenljivo izvršitvene funkcije. Na vzorcu 3,5 do 6 let starih otrok iz gospodinjstev $\mathrm{z}$ nizkimi prihodki sta preverili, ali izvršitvene funkcije otroka leto dni pred njegovim vstopom $v$ vrtec prek mediatorja razumevanje napačnih prepričanj, izmerjeno prav tako leto dni pred vstopom $v$ vrtec, dobro napovedujejo otrokovo socialno kompetentnost $\mathrm{v}$ prvem letu otrokovega obiskovanja vrtca. Ugotovili sta, da otrokovo socialno razumevanje pred vstopom $\mathrm{v}$ vrtec pojasni unikaten del variance socialne kompetentnosti v prvem letu obiskovanja vrtca, in sicer tudi ob nadzoru razvitosti izvršitvenih funkcij. Prav tako tudi zgodnejša socialna kompetentnost pri otroku pojasni unikaten del variance njegovega kasnejšega socialnega razumevanja. Obenem pa so otrokove izvršitvene funkcije pred vstopom v vrtec dober napovednik otrokovega poznejšega socialnega razumevanja $\mathrm{v}$ času njegove vključenosti $\mathrm{v}$ vrtec, in sicer prek mediatorja, ki je socialno razumevanje pred vstopom v vrtec.

Ker teorija uma zadeva otrokovo razumevanje mentalnih stanj drugih, je morda samoumevno pričakovati, da se dobro razvita teorija uma povezuje $\mathrm{z}$ otrokovimprosocialnim vedenjem. Učiteljiin opazovalci res zaznavajo otroke $\mathrm{z}$ boljšim razumevanjem uma (in čustev) kot bolj socialno kompetentne (Cassidy, Werner, Rourke, Zubernis in Balaraman, 2003; Watson, Nixon, Wilson in Capage, 1999). Vendar pa odnos med otrokovo teorijo uma in socialnim vedenjem ni tako enoznačen in enostaven, da v ozadju antisocialnega vedenja nujno obstoji primanjkljaj na področju teorije uma. Obstajajo sicer nekateri dokazi iz klinične prakse, da se manj razvita teorija uma povezuje $\mathrm{z}$ vedenjskimi težavami (Fahie in Symons, 2003). Po drugi strani pa odsotnost otrokove teorije uma sodeč po nekaterih rezultatih raziskav pomembno napoveduje njegovo agresivno vedenje, po drugih pa ne. To je po ugotovitvah Renoufa in sodelavcev (2010b) odraz različnosti funkcije agresivnega vedenja. Študije agresivnega vedenja namreč ločujejo med dvema vrstama agresije glede na njeno funkcijo, in sicer reaktivno in proaktivno. Prva oblika je impulziven odziv na resnično ali namišljeno grožnjo, medtem ko je druga načrtovana in služi doseganju posameznikovega cilja ali dominacije nad drugimi in ni izzvana (npr. Renouf idr., 2010b). V okvir slednje sodi tudi ustrahovanje vrstnikov oz. vrstniško nasilje, ko močnejši otrok napade šibkejšega, navadno brez provokacije s strani žrtve (Caravita, Di Blasio in Salmivalli, 2010). Skladno z njunima funkcijama sta obe obliki agresivnega vedenja na različen način povezani z otrokovimi socialno-spoznavnimi sposobnostmi, tudi s teorijo uma.

Reaktivno agresivni otroci naj bi bili nagnjeni $\mathrm{k}$ zaznavanju sovražnih namenov drugih v situacijah, ki imajo zanje negativen izid, kar naj bi bil po prepričanju nekaterih avtorjev odraz pomanjkljivo razvite teorije uma (Runions in Keating, 2007). Tako so lahko otroci, ki imajo težave $\mathrm{z}$ zavzemanjem perspektive drugega, nagnjeni $\mathrm{k}$ agresivnim reakcijam med socialnimi interakcijami, ki vključujejo resnično ali namišljeno provokacijo oz. grožnjo, in sicer zgolj na osnovi negativnega izida situacije namesto na osnovi namena nasprotne osebe. Po drugi strani pa je proaktivna agresivnost pozitivno povezana $\mathrm{z}$ višje razvitimi socialno-spoznavnimi sposobnostmi; proaktivno agresivni otroci lahko dobro razumejo namene drugega v socialni interakciji, tudi v situacijah, ki vključujejo negativen izid zanje. Ti otroci se namreč agresivno odzovejo takrat, kadar verjamejo, da bodo na ta način dosegli kak oseben cilj (Crick in Dodge, 1996).

Vsi otroci z manj razvito teorijo uma pa niso nagnjeni k pogosti reaktivni agresivnosti. Povezanost med otrokovimi socialno-spoznavnimi sposobnostmi in socialnim vedenjem namreč ni linearna - običajno je posredi moderator socialno okolje. Manj razvita teorija uma je tako lahko dejavnik tveganja za reaktivno agresivnost pri tistih otrocih, ki so izpostavljeni negativnim izkušnjam iz okolja, kot so zlorabe $\mathrm{v}$ družini ali s strani vrstnikov (Hughes in Ensor, 2007; Renouf idr., 2010b). A. Renouf in sodelavci (2010b) so v vzdolžni študij pri 574 otrocih dvojčkih raziskovali moderatorski učinek vrstniškega nasilja na odnos med teorijo uma ter reaktivno in proaktivno agresivnostjo otrok v vrtcu. Razvitost teorije uma so izmerili, ko so bili otroci stari pet let, obe vrsti agresivnosti in vrstniško nasilje pa leto kasneje, in sicer s pomočjo ocen vzgojiteljic. Skladno s svojimi predpostavkami so ugotovili, da je manj razvita teorija uma pri petih letih starosti povezana $\mathrm{z}$ visoko stopnjo otrokove reaktivne agresivnosti leto pozneje, vendar samo pri otrocih, ki so pogosto žrtve vrstniškega nasilja. Otroci, ki slabše prepoznavajo namene drugih ljudi, se morajo zanesti na lastno zaznavo resničnosti, ki pa temelji na izkušnjah z drugimi, in če so te negativne, se otrokova pričakovanja $\mathrm{v}$ zvezi z drugimi generalizirajo. Reaktivna agresivnost pa dalje vodi v še več zavračanja in nasilja pri vrstnikih - tako so ti otroci prikrajšani za priložnosti, ki bi jim omogočile pozitivne socialne interakcije in tako razvoj 
teorije uma. Nasprotno je bila bolj razvita teorija uma povezana s kasnejšo visoko stopnjo proaktivne agresivnosti, prav tako pri otrocih, ki so bili deležni veliko vrstniškega nasilja. Avtorji sklepajo, da so si na ta način otroci poskušali izboljšati socialni položaj in morda pri višji starosti agresivno vedenje opustijo. Interakcija med obema vrstama agresije je bila v študiji nadzorovana, razlike med spoloma $\mathrm{v}$ povezanosti med teorijo uma in otrokovim agresivnim vedenjem pa avtorji niso ugotovili.

Povezanost teorije uma $\mathrm{z}$ agresivnostjo ni odvisna samo od funkcije, temveč tudi od oblike agresivnosti. A. Renouf in sodelavci (2010a) so v drugi svoji študiji ugotovili, da se teorija uma povezuje le s posredno agresivnostjo (npr. opravljanje, socialno izključevanje), s fizično pa ne (npr. udarjanje, brcanje), pri čemer je prva povezanost statistično pomembna samo pri otrocih, ki izražajo nizko do povprečno raven prosocialnega vedenja (nadzorovane so bile spremenljivke besednjak, spol in fizična agresija). Rezultati so pokazali, da imajo posredno agresivni otroci dobro razvito teorijo uma. Ko je otrok posredno agresiven, namreč manipulira $\mathrm{z}$ mentalno reprezentacijo drugih (npr. povzroči napačno prepričanje $\mathrm{v}$ drugih $\mathrm{s}$ širjenjem govoric o nekom) in tako vpliva na njihovo vedenje (npr. doseže izključitev osebe iz vrstniške skupine). Obenem teorija uma pomaga pri zakrivanju namena otroka, saj se ta trudi svoje vedenje prikazati kot kar se da nevtralno (Sutton, Smith in Swettenham, 1999). Sutton in sodelavci (1999) so predstavili kritičen pogled na stereotipno predstavo o nasilnežih kot podpovprečno inteligentnih posameznikih, ki so nesposobni uvideti perspektivo drugega in ocenjujejo svet okrog njih zgolj skozi svoje lastne oči. Nasilništvo kot sistematično zlorabljanje moči namreč mnogokrat temelji na nadpovprečnem razumevanju oz. »branju« uma drugih; primanjkljaj pri teh otrocih je tako kvečjemu na področju empatije, ne pa na področju teorije uma.

Povezanost teorije uma $\mathrm{z}$ nasilništvom je bila preučevana tudi pri mladostnikih. S. C. S Caravita in sodelavke (2010) so v raziskavo vključile različne udeležence glede na njihovo vlogo v vrstniškemu nasilju - voditelje, zaščitnike in žrtve - ter njihove med- in znotrajosebnostne značilnosti: empatijo, socialno preferenco (izmerjeno z že prej opisano sociometrično metodo po sistemu, kdo med vrstniki je vsakemu otroku najbolj/najmanj všeč), zaznano priljubljenost (kdo od vrstnikov se jim zdi najbolj priljubljen) in spol. Avtorice so prav tako ugotovile povezanost nasilništva $\mathrm{z}$ visoko razvito teorijo uma, in sicer so voditelji dosegali visoke ravni socialnega razumevanja, vendar je to veljalo le za dečke, branitelji pa prav tako, kar pa je veljalo za oba spola. Empatija in zaznana priljubljenost nista moderirali nobene od povezanosti, socialna preferenca pa se je pokazala kot moderator med teorijo uma in zaščitništvom. Dečki, ki so dobro sprejeti med svojimi vrstniki, torej bolj verjetno uporabijo svoje socialno razumevanje na pozitiven način, hkrati pa ta sprejetost služi kot zaščitni dejavnik pred nasilneži. Tudi empatija po ugotovitvah avtoric v manjši meri moderira povezanost med teorijo uma in zaščitništvom, torej spodbuja prosocialno vedenje. $\mathrm{V}$ obdobju mladostništva za razliko od izsledkov raziskav, narejenih za zgodnejša razvojna obdobja, pa manj razvita teorija uma ne predstavlja tveganja, da mladostnik postane žrtev nasilništva, saj avtorice povezanosti med tema spremenljivkama niso našle.

Učinek otrokovega spola na odnos med otrokovim socialnim razumevanjem in njegovo socialno kompetentnostjo potrjujejo tudi nekateri drugi avtorji (Walker, 2005). Vzgojiteljice namreč ocenjujejo tri- do petletne dečke, ki dosežejo boljše rezultate na preizkusu napačnih prepričanj, kot pogosteje agresivne in redkeje plašne $\mathrm{v}$ odnosu do vrstnikov, deklice $\mathrm{z}$ boljšim socialnim razumevanjem pa kot bolj prosocialne. Ti rezultati govorijo v prid razlagam, da otroci, ki izražajo višje socialno razumevanje, to uporabijo za dosego svojih ciljev, v tem primeru za vzpostavitev želenega odnosa $\mathrm{z}$ vrstniki v vrtcu.

\section{Zaključek}

V prispevku smo pregledali več študij s področja odnosov med teorijo uma ter socialnimi odnosi in socialno kompetentnostjo. Če poskušamo opredeliti in združiti socialne dejavnike, ki so po ugotovitvah raziskovalcev pomembni za razvoj otrokovega socialnega razumevanja, potem bi moral imeti najugodnejše pogoje za dobro razvito teorijo uma otrok, ki živi $\mathrm{v}$ družini $\mathrm{z}$ dobrim socialnoekonomskim položajem (Cutting in Dunn, 1999), je deležen pogostih pogovorov, $\mathrm{v}$ katerih ima priložnost slišati izraze za mentalna stanja s strani staršev (npr. usmerjevalni govor) (Ontai in Thompson, 2008), je varno navezan na pomembno osebo (Meins idr., 1998) in ni deležen avtoritativne vzgoje, temveč ustreznih načinov discipliniranja (npr. izpostavljanje občutkov žrtve) (Ruffman idr., 1999), ima kakovostne odnose s primerno starim (-i) sorojencem (-i) (Perner idr., 1994), pa tudi s sorodniki iz širšega družinskega kroga (Lewis idr., 1996), v vrstniški skupini pa ni socialno izključen, temveč vstopa $\mathrm{v}$ interakcije $\mathrm{z}$ različno starimi otroki (Slaughter idr., 2002). Vendarle pa vse navedeno še ne zagotavlja, da bo otrok svoje pridobljeno socialno razumevanje uporabljal na prosocialen način. To znanje namreč lahko služi tudi izražanju nezaželenih oblik vedenja, kot je npr. ustrahovanje in manipuliranje vrstnikov. Poleg tega je nizko razvita teorija uma lahko dejavnik tveganja predvsem pri otrocih, ki živijo v neugodnih socialnih in ekonomskih razmerah. 
V prispevku smo želeli prikazati, da se učinkov med različnimi dejavniki in teorijo uma ne da opisati enosmerno. Starši, sorojenci in vrstniki tako po eni strani lahko spodbujajo razvoj otrokove teorije uma, po drugi pa so v socialnih interakcijah lahko deležni učinkov otrokove bolj ali manj razvite teorije uma. Vrstniška kultura je tako spodbuden dejavnik za razvoj teorije uma, obenem pa so komponente teorije uma, kot je razumevanje perspektive drugega, ena ključnih dimenzij koncepta prijateljstva, ki se razvija že v zgodnjem otroštvu (Marjanovič Umek, Zupančič, Fekonja, Lešnik Musek in Kavčič, 2001). Tudi učinek vrstniške izključenosti na razvoj otrokove teorije uma je verjetno dvosmeren. Raziskovalci sicer ugotavljajo, da se učinki socialne izključenosti na teorijo uma $\mathrm{z}$ otrokovo starostjo povečujejo, pri tem pa ni jasno, ali so otroci z manj razvito teorijo uma bolj verjetno socialno izključeni, ali pa so socialno izključeni zaradi katerega drugega dejavnika in posledično nimajo dovolj priložnosti za optimalen razvoj teorije uma $\mathrm{v}$ interakcijah z drugimi (Badenes idr., 2000). Nadalje se starši odzivajo na svoje otroke v smislu prilagajanja otrokovim individualnim značilnostim, zato učinki njihovega vedenja, predvsem pa govora, za otrokovo teorijo uma niso nujno neodvisni od že obstoječih otrokovih sposobnosti na tem področju ali drugih spoznavnih področij, kot je npr. otrokova inteligentnost. Nismo zasledili, da bi katera od študij na tem področju raziskovanja vključila tudi razlikovalno odzivanje staršev do njihovih otrok, kar bi zagotovo doprineslo $\mathrm{k}$ razumevanju pomena družinskih dejavnikov za otrokovo teorijo uma, saj je mogoče, da razlikovalno odzivanje staršev pri otroku spodbuja zavzemanje perspektive drugega $v$ smislu tehtanja pravičnosti ipd.

Opisane študije imajo tudi nekatere druge pomanjkljivosti. Pri učinkih otrokovih interakcij s starši na razvoj teorije uma so npr. večinoma vključene samo mame, kar pomeni, da morebitni specifični prispevki $\mathrm{k}$ razvoju socialnega razumevanja otrok, ki izhajajo iz očetovega pogovora z njimi, niso znani. Prav tako pri preučevanju učinkov sorojencev nekateri avtorji v svoje raziskovalne modele ne vključijo razlike v starosti med sorojencema, ampak jih razdelijo glede na to, ali so mlajši ali starejši od otrok v vzorcu. Nekateri avtorji ne ločujejo niti učinka starejših sorojencev od učinka mlajših sorojencev. Problem študij o učinkih sorojencev na razvoj otrokove teorije uma je tudi to, da raziskovalci ne upoštevajo učinka vrstnikov in ga tako ne ločijo od učinka sorojencev. V skladu s tem prilagojeni raziskovalni načrti bi morda odgovorili na vprašanje, kaj je pravzaprav tisti pozitivni učinek drugega otroka za razvoj teorije uma - medosebna komunikacija ali morda možnost prisostvovanja pogovorom sorojenca s starši oz. drugimi sorojenci ali vrstnika z drugimi otroki v skupini ipd. Morda gre pri tem za sorodnosti v učinkih vrstnikov in sorojencev na otrokovo teorijo uma $\mathrm{v}$ smislu pomena bodisi aktivne bodisi pasivne interakcijske vloge, vključevanja v sociodramsko igro, posnemanja, učinka posredovanja odrasle osebe (starš oz. vzgojiteljica) ipd.

Ko govorimo o povezanosti teorije uma $\mathrm{Z}$ nasilništvom, zelo malo raziskovalcev razpravlja o praktičnem pomenu izsledkov npr. za klinično prakso in za načrtovanje ukrepov proti nasilništvu v šolah. Napačna predpostavka o tem, da imajo nasilni otroci težave z zavzemanjem perspektive drugega, lahko vodi do povsem napačnih pristopov $\mathrm{k}$ reševanju problema v svetovalni dejavnosti. Na tem področju se odpirajo široke raziskovalne možnosti $\mathrm{v}$ smislu preučevanja dodatnih spremenljivk, kot je npr. temperament oz. osebnost otroka, ki se zelo verjetno vključuje v apliciranje otrokovega znanja o drugih na njegovo ravnanje $\mathrm{V}$ zvezi $\mathrm{z}$ njimi. Malo je znanega tudi o dolgoročnih učinkih otrokove teorije uma na njegovo kasnejše vedenje. Kaj se dogaja s otroki, ki so bili socialno izključeni $\mathrm{v}$ zgodnjem otroštvu, kasneje $\mathrm{v}$ mladostništvu? In po drugi strani tudi o dolgoročnih učinkih spodbudnih dejavnikov za razvoj teorije uma ne vemo veliko - ali se učinek staršev, ki so svojemu otroku pripisovali um $\mathrm{v}$ zgodnjem otroštvu, izraža tudi $\mathrm{v}$ vedenju mladostnika? Je tak otrok uspešnejši $\mathrm{v}$ odnosih $\mathrm{z}$ vrstniki v primerjavi s sorojenci na račun učinka tega družinskega dejavnika?

Od pregledanih študij so nekatere tudi precej metodološko vprašljive. Raziskovalci pogosto ocenijo teorijo uma samo z eno ali komaj nekaj več nalogami - aplikativnost na ta način izmerjenih sposobnosti na resnične, vsakdanje situacije, je seveda vprašljiva. Večina obravnavanih študij je prečnih, avtorji pa pri tem pogosto precej nekritično razlagajo smer ugotovljenih učinkov. Nekateri avtorji tudi ne opredelijo natančno, kaj sploh je tisto, kar preučujejo - socialno razumevanje je tako ponekod pojmovano kot zgolj razumevanje uma, ponekod kot tudi razumevanje čustev, nejasne pa so tudi notranje povezave med temi kategorijami. Iz opisov nekaterih avtorjev tako lahko sklepamo, da socialno razumevanje enačijo s teorijo uma, iz drugih pa, da obstaja več oblik socialnega razumevanja. V tem smislu je problematično tudi merjenje izrazov za opisovanje mentalnih stanj. Različni konteksti poročanja oz. govora verjetno vplivajo na to, katere mentalne kategorije oseba v tistem trenutku izpostavlja, pri čemer se morda s teorijo uma ne povezujejo vse na enak način (npr. izrazi za čustva drugače kot izrazi za misli). Vprašljiv je tudi učinek socialno-ekonomskega položaja družine na razvoj otrokove teorije uma, saj se ta $\mathrm{v}$ študijah obravnava kot mera okolja, a tudi te so lahko do določene mere pod vplivom genetskih dejavnikov (socialno-ekonomski položaj torej ni nujno korektna mera okolja, ki so ga sorojenci v isti 
družini med seboj delijo). Iz spoznanj pregledanih študij pa lahko sklepamo, da naj socialno-ekonomski položaj družine ne bi bil pomembnejši dejavnik za razvoj teorije uma od prisotnosti kompetentne osebe (npr. Yagmurlu idr., 2005). Sklepamo lahko tudi, da je v primeru neugodnih družinskih razmer, ki navadno izhajajo predvsem iz nizkega socialno-ekonomskega položaja, učinek odrasle osebe v smislu kakovostnih interakcij lahko zaščitni dejavnik, ko gre za razvoj otrokovega socialnega razumevanja, učinek sorojencev pa ne (Cutting in Dunn, 1999).

Naš pregled študij ima zagotovo tudi svoje pomanjkljivosti. Nedvomno smo zanemarili nekatere pomembne koncepte, ki se povezujejo z otrokovo teorijo uma in imajo pomembne učinke na otrokovo socialno življenje, saj smo sledili trendom $\mathrm{v}$ raziskovanju in v začetku zapisanim kriterijem. Tako zanemarjeno področjejezagotovonajprej otrokov govor. Najverjetneje so socialne interakcije, v katere otrok vstopa, povezane s teorijo uma prek razvoja govora. Socialni odnosi imajo tako osrednje mesto $\mathrm{v}$ otrokovem socialnem razvoju, saj se otroci pomenov za besede naučijo prek dejavnosti - višji spoznavni procesi so namreč socialni, ne osebni; jezik nastopa kot mediator med najprej medosebnim in potem znotrajosebnim vedenjem (Carpendale in Lewis, 2004; Vygotskij, 2010). Mnoge študije potrjujejo povezanost otrokovega govora $\mathrm{z}$ njegovo teorijo uma (npr. Ronald idr., 2006). Nadalje se na tem mestu nismo veliko ukvarjali $\mathrm{z}$ razlikami med spoloma $\mathrm{v}$ razvoju teorije uma, na obstoj katerih kažejo nekateri rezultati, kot je npr. superiornost deklic pri določenih nalogah za ocenjevanje teorije uma, predvsem pri preizkusu belih laži (npr. Yagmurlu idr., 2005). Prihodnje raziskovanje bi med iskanje povezav socialnih dejavnikov $\mathrm{Z}$ individualnimi razlikami v razvoju teorije uma lahko strukturirano vključevalo tudi spol otroka (npr. učinek sorojencev je lahko različen, ali gre za deklico ali dečka, posebej, če je posredi še kakšna druga spremenljivka, npr. razlikovalno odzivanje staršev).

Zanimivo je tudi, da nismo zasledili študij, ki bi med preučevane dejavnike razvoja teorije uma poleg staršev, sorojencev in vrstnikov vključevale tudi učinek vzgojiteljice oz. vrtca. Vloga vzgojiteljice kot kompetentne osebe je v tem smislu povsem nejasna in bi lahko pomembno prispevala $\mathrm{k}$ razumevanju pomena socialnih interakcij za razvoj teorije uma otrok, vključenih v vrtec. Tudi ko gre za učinke otrokovih interakcij z osebami iz širše družine na teorijo uma, so ugotovljeni pozitivni učinki opredeljeni zgolj s količino teh interakcij, ne pa z njihovo naravo in npr. tem, v čem se razlikujejo od interakcij, ki jih ima otrok $z$ drugimi kompetentnimi osebami. Nadalje se, ko govorijo o učinku vrstnikov v vrtcu na otrokovo teorijo uma, avtorji premalo ukvarjajo s tem, kakšni so vrstniki, $\mathrm{s}$ katerimi preučevani otroci vstopajo $\mathrm{v}$ interakcije. Ponavadi so opredeljeni zgolj s starostjo (npr. starejše in mlajše skupine), zanimive pa bi bile tudi študije, $\mathrm{v}$ katerih bi raziskovalci nadzorovali raven razvitosti teorije uma pri vseh otrocih v vrstniški skupini in merili njihove medsebojne učinke, tudi $\mathrm{v}$ kombinaciji $\mathrm{s}$ še kakšno spremenljivko, npr. govorno kompetentnostjo, osebnostjo otroka ali vlogo vzgojiteljice. Tudi ob pregledu ugotovljenih povezanosti med otrokovo navezanostjo na pomembne osebe in njegovo teorijo uma smo opozorili na to, da študije ne ponujajo enoznačnih ugotovitev o tem, ali je ta povezanost res pomembna, pri čemer je še posebej vprašljivo, kaj je tisto pri navezanosti otroka, kar ima učinek na teorijo uma, če to ni narava komunikacije s pomembno osebo (Ontai in Thompson, 2008).

Po vsem zapisanem se vedno bolj kaže potreba po kompleksnih raziskovalnih načrtih, ki bi poskušali oblikovati model učinkov med različnimi dejavniki okolja $\mathrm{v}$ odnosu do razvoja otrokove teorije uma na eni strani ter med ravnjo razvitosti teorije uma in socialnim vedenjem otroka na drugi; eden boljših, a še vedno precej splošnih poskusov je model, ki ga predlagata Carpendale in Lewis (2004). Prispevek bi lahko predstavljal ogrodje takšnega kompleksnega raziskovalnega načrta, ki bi teorijo uma obravnaval $\mathrm{z}$ dveh strani in vključeval čim več tistih dejavnikov, ki so se v študijah o povezanosti teorije uma s socialnim okoljem izkazali za pomembne. Dejstvo je, da so odnosi med obravnavanimi koncepti zapleteni in da otrok teorije uma ne osvoji sam od sebe. Socialno razumevanje se očitno razvije znotraj interakcij $\mathrm{Z}$ drugimi osebami, pri čemer lahko z gotovostjo trdimo, da pomen teh interakcij ni (samo) v njihovi količini, ampak predvsem kakovosti.

\section{Literatura}

Badenes, L. V., Estevan, R. A. C. in Bacete, F. J. (2000). Theory of mind and peer rejection at school. Social Development, 9(3), 271-283.

Brown, J. R., Donelan-McCall, N. in Dunn, J. (1996). Why talk about mental states? The significance of children's conversations with friends, siblings, and mothers. Child Development, 67(3), 836-849.

Caravita, S. C., Di Blasio, P. in Salmivalli, C. (2010). Early adolescents' participation in bullying: Is ToM involved? The Journal of Early Adolescence, 30(1), 138-170.

Carpendale, J. in Lewis, C. (2006a). Social interaction and the development of social understanding: The role of relationships in social cognitive development. V J. Carpendale in C. Lewis (ur.), How children develop social understanding (str. 133-157). Oxford: Blackwell publishing.

Carpendale, J. in Lewis, C. (2006b). Social understanding and children's social lives. How children develop social understanding (str. 205-230). Oxford: Blackwell publishing. 
Carpendale, J. I. in Lewis, C. (2004). Constructing an understanding of mind: The development of children's social understanding within social interaction. V J. Carpendale in C. Lewis (ur.), Behavioral and Brain Sciences, 27(1), 79-151.

Cassidy, K. W., Fineberg, D. S., Brown, K. in Perkins, A. (2005). Theory of mind may be contagious, but you don't catch it from your twin. Child Development, 76(1), 97-106.

Cassidy, K. W., Werner, R. S., Rourke, M., Zubernis, L. S. in Balaraman, G. (2003). The relationship between psychological understanding and positive social behaviors. Social Development, 12(2), 198-221.

Crick, N. R. in Dodge, K. A. (1996). Social informationprocessing mechanisms on reactive and proactive aggression. Child Development, 67(3), 993-1002.

Cutting, A. L. in Dunn, J. (1999). Theory of mind, emotion understanding, language, and family background: Individual differences and interrelations. Child Development, 70(4), 853-865.

de Rosnay, M. in Hughes, C. (2006). Conversation and theory of mind: Do children talk their way to sociocognitive understanding? British Journal of Developmental Psychology, 24(1), 7-37.

Fahie, C. M. in Symons, D. K. (2003). Executive functioning and theory of mind in children clinically referred for attention and behavior problems. Journal of Applied Developmental Psychology, 24(1), 51-73.

Fernyhough, C. (2008). Getting Vygotskian about theory of mind: Mediation, dialogue, and the development of social understanding. Developmental Review, 28(2), 225-262.

Foote, R. C. in Holmes-Lonergan, H. A. (2003). Sibling conflict and theory of mind. British Journal of Developmental Psychology, 21(1), 45-58.

Howe, N., Rinaldi, C. M., Jennings, M. in Petrakos, H. (2002). "No! The lambs can stay out because they got cozies!": Constructive and destructive sibling conflict, pretend play, and social understanding. Child Development, 73(5), 1460-1473.

Hughes, C. in Cutting, A. L. (1999). Nature, nurture, and individual differences in early understanding of mind. Psychological Science, 10(5), 429-432.

Hughes, C., Deater-Deckard, K. in Cutting, A. L. (1999). "Speak roughly to your little boy?" Sex differences in the relations between parenting and preschoolers' understanding of mind. Social Development, 8(2), 143-160.

Hughes, C. in Ensor, R. (2005). Executive function and theory of mind in 2 year olds: A family affair? Developmental Neuropsychology, 28(2), 645-668.

Hughes, C. in Ensor, R. (2006). Behavioural problems in 2-year-olds: Links with individual differences in theory of mind, executive function and harsh parenting. Journal of Child Psychology and Psychiatry, 47(5), 488-497.
Hughes, C. in Ensor, R. (2007). Positive and protective: Effects of early theory of mind on problem behaviors in at-risk preschoolers. Journal of Child Psychology and Psychiatry, 48(10), 1025-1032.

Hughes, C., Fujisawa, K. K., Ensor, R., Lecce, S. in Marfleet, R. (2006). Cooperation and conversations about the mind: A study of individual differences in 2-yearolds and their siblings. British Journal of Developmental Psychology, 24(1), 53-72.

Hughes, C., Jaffee, S. R., Happe, F., Taylor, A., Caspi, A. in Moffitt, T. E. (2005). Origins of individual differences in theory of mind: From nature to nurture? Child Development, 76(2), 356-370.

Jenkins, J. M. in Astington, J. W. (1996). Cognitive factors and family structure associated with theory of mind development in young children. Developmental Psychology, 32(1), 70-78.

Kavčič, T. in Zupančič, M. (2006). Parental differential treatment of siblings in childhood. Psihološka $\mathrm{Ob}$ zorja/Horizons of Psychology, 15(4), 5-24.

Lane, J. D., Wellman, H. M., Olson, S. L., LaBounty, J. in Kerr, D. C. (2010). Theory of mind and emotion understanding predict moral development in early childhood. British Journal of Developmental Psychology, 28(4), 871-889.

Lewis, C., Freeman, N. H., Kyriakidou, C., MaridakiKassotaki, K. in Berridge, D. M. (1996). Social influences on false belief access: Specific sibling influences or general apprenticeship? Child Development, 67(6), 2930-2947.

Marjanovič Umek, L. (2009). Spoznavni razvoj v zgodnjem otroštvu [Cognitive development in early choldhood]. V L. Marjanovič Umek in M. Zupančič (ur.), Razvojna psihologija [Developmental psychology] (str. 291-314). Ljubljana: Znanstvena založba Filozofske fakultete.

Marjanovič Umek, L., Zupančič, M., Fekonja, U., Lešnik Musek, P. in Kavčič, T. (2001). Socialni razvoj v zgodnjem otroštvu in teorija uma [Social development in early childhood and theory of mind]. V L. Marjanovič Umek in M. Zupančič (ur.), Razvojna psihologija: izbrane teme [Developmental psychology: Selected works] (str. 42-59). Ljubljana: Oddelek za psihologijo Filozofske fakultete.

McAlister, A. in Peterson, C. (2007). A longitudinal study of child siblings and theory of mind development. Cognitive Development, 22(2), 258-270.

McAlister, A. in Peterson, C. C. (2006). Mental playmates: Siblings, executive functioning and theory of mind. British Journal of Developmental Psychology, 24(4), 733-751.

McElwain, N. L. in Volling, B. L. (2004). Attachment security and parental sensitivity during infancy: Associations with friendship quality and false-belief understanding at age 4. Journal of Social and Personal Relationships, 21(5), 639-667. 
Meins, E., Fernyhough, C., Russell, J. in Clark-Carter, D. (1998). Security of attachment as a predictor of symbolic and mentalising abilities: A longitudinal study. Social Development, 7(1), 1-24.

Meins, E., Fernyhough, C., Wainwright, R., Gupta, M. D., Fradley, E. in Tuckey, M. (2002). Maternal mindmindedness and attachment security as predictors of theory of mind understanding. Child Development, 73(6), 1715-1726.

Ontai, L. L. in Thompson, R. A. (2008). Attachment, parent-child discourse and theory-of-mind development. Social Development, 17(1), 47-60.

Pears, K. C. in Moses, L. J. (2003). Demographics, parenting, and theory of mind in preschool children. Social Development, 12(1), 1-19.

Perner, J., Ruffman, T. in Leekam, S. R. (1994). Theory of mind is contagious: You catch it from your sibs. Child Development, 65(4), 1228-1238.

Peterson, C. C. (2000). Influence of siblings' perspectives on theory of mind. Cognitive Development, 15(4), 435-455.

Peterson, C. C., Garnett, M., Kelly, A. in Attwood, T. (2009). Everyday social and conversation applications of theory-of-mind understanding by children with autism-spectrum disorders or typical development. European Child \& Adolescent Psychiatry, 18(2), 105-115.

Peterson, C. C. in Siegal, M. (2002). Mindreading and moral awareness in popular and rejected preschoolers. British Journal of Developmental Psychology, 20(2), 205-224.

Racine, T. P., Carpendale, J. I. in Turnbull, W. (2006). Cross-sectional and longitudinal relations between mother-child talk about conflict and children's social understanding. British Journal of Psychology, 97(4), 521-536.

Randell, A. C. in Peterson, C. C. (2009). Affective qualities of sibling disputes, mothers' conflict attitudes, and children's theory of mind development. Social Development, 18(4), 857-874.

Razza, R. A. in Blair, C. (2009). Associations among falsebelief understanding, executive function, and social competence: A longitudinal analysis. Journal of Applied Developmental Psychology, 30(3), 332-343.

Recchia, H. E. in Howe, N. (2009). Associations between social understanding, sibling relationship quality, and siblings' conflict strategies and outcomes. Child Development, 80(5), 1564-1578.

Renouf, A., Brendgen, M., Parent, S., Vitaro, F., Zelazo, P. D., Boivin, M., Dionne, G., Tremblay, R. E., Perusse, D. in Seguin, J. R. (2010a). Relations between theory of mind and indirect and physical aggression in kindergarten: Evidence of the moderating role of prosocial behaviors. Social Development, 19(3), 535-555.

Renouf, A., Brendgen, M., Seguin, J. R., Vitaro, F., Boivin, M., Dionne, G., Tremblay, R. E. in Perusse, D. (2010b). Interactive links between theory of mind, peer victimization, and reactive and proactive ag- gression. Journal of Abnormal Child Psychology: An official publication of the International Society for Research in Child and Adolescent Psychopathology, 38(8), 1109-1123.

Ronald, A., Happe, F., Hughes, C. in Plomin, R. (2005). Nice and nasty theory of mind in preschool children: Nature and nurture. Social Development, 14(4), 664-684.

Ronald, A., Viding, E., Happe, F. in Plomin, R. (2006). Individual differences in theory of mind ability in middle childhood and links with verbal ability and autistic traits: A twin study. Social Neuroscience, 1(3-4), 412-425.

Ruffman, T., Perner, J., Naito, M., Parkin, L. in Clements, W. A. (1998). Older (but not younger) siblings facilitate false belief understanding. Developmental Psychology, 34(1), 161-174.

Ruffman, T., Perner, J. in Parkin, L. (1999). How parenting style affects false belief understanding. Social Development, 8(3), 395-411.

Ruffman, T., Slade, L., Devitt, K. in Crowe, E. (2006). What mothers say and what they do: The relation between parenting, theory of mind, language and conflict/cooperation. British Journal of Developmental Psychology, 24(1), 105-124.

Runions, K. C. in Keating, D. P. (2007). Young children's social information processing: Family antecedents and behavioral correlates. Developmental Psychology, 43(4), 838-849.

Sabbagh, M. A. in Callanan, M. A. (1998). Metarepresentation in action: 3-, 4-, and 5-year-olds' developing theories of mind in parent-child conversations. Developmental Psychology, 34(3), 491-502.

Slaughter, V., Dennis, M. J. in Pritchard, M. (2002). Theory of mind and peer acceptance in preschool children. British Journal of Developmental Psychology, 20(4), 545-564.

Slaughter, V., Peterson, C. C. in Mackintosh, E. (2007). Mind what mother says: Narrative input and theory of mind in typical children and those on the autism spectrum. Child Development, 78(3), 839-858.

Sutton, J., Smith, P. K. in Swettenham, J. (1999). Bullying and "theory of mind": A critique of the "social skills deficit' view of anti-social behaviour. Social Development, 8(1), 117-127.

Symons, D. K. in Clark, S. E. (2000). A longitudinal study of mother-child relationships and theory of mind in the preschool period. Social Development, 9(1), 3-23.

Symons, D. K., Fossum, K.-L. M. in Collins, T. (2006). A longitudinal study of belief and desire state discourse during mother-child play and later false belief understanding. Social Development, 15(4), 676-691.

Symons, D. K., Peterson, C. C., Slaughter, V., Roche, J. in Doyle, E. (2005). Theory of mind and mental state discourse during book reading and story-telling tasks. British Journal of Developmental Psychology, 23(1), 81-102. 
Vygotsky, L. S. (2010). Mišljenje in govor [Thought and Language]. Ljubljana: Pedagoška fakulteta.

Walker, S. (2005). Gender differences in the relationship between young children's peer-related social competence and individual differences in theory of mind. The Journal of Genetic Psychology: Research and Theory on Human Development, 166(3), 297-312.

Wang, Y. in Su, Y. (2009). False belief understanding: Children catch it from classmates of different ages. International Journal of Behavioral Development, 33(4), 331-336.

Watson, A. C., Nixon, C. L., Wilson, A. in Capage, L. (1999). Social interaction skills and theory of mind in young children. Developmental Psychology, 35(2), 386-391.

Wellman, H. M., Cross, D. in Watson, J. (2001). Meta-analysis of theory-of-mind development: The truth about false belief. Child Development, 72(3), 655-684.

Woolfe, T., Want, S. C. in Siegal, M. (2002). Signposts to development: Theory of mind in deaf children. Child Development, 73(3), 768-778.

Yagmurlu, B., Berument, S. K. in Celimli, S. (2005). The role of institution and home contexts in theory of mind development. Journal of Applied Developmental Psychology, 26(5), 521-537. 